\title{
Walerij ACZKASOW
}

Petersburski Uniwersytet Państwowy

val-achkasov@yandex.ru

\section{POTENCJAŁ KONFLIKTOWY FEDERALIZMU ETNICZNEGO W ROSJI}

\section{ABSTRACT Conflict Potential of Russian Ethnic Federalism}

The uses of federative structure of the Russian state as a tool of regulation of interethnic conflicts and ways of stable democracy have been analyzed. The author accents the various models of the national - territorial method of self-determination of ethnic communities. Particular attention is given to evaluation of negative consequences of reflection of ethnicity in the Russian structures.

Keywords: the Russian state, ethnic federalism, nationalism, conflict potential, the politicization of ethnicity

Słowa kluczowe: państwo rosyjskie, etnofederalizm, nacjonalizm, potencjał konfliktowy, polityzacja etniczności 
W dzisiejszym świecie prawie nie ma już krajów monoetnicznych i monokulturowych, dlatego praktycznie we wszystkich społeczeństwach pojawia się problem poszukiwania i zastosowania skutecznych mechanizmów koordynacji interesów różnych grup (segmentów) społecznych o charakterze religijnym, językowym, ideologicznym, regionalnym, kulturowym, rasowym czy etnicznym. Niektóre państwa, realizujące któryś z modeli federalizmu, rzeczywiście dążą do integracji różnych grup etnicznych w wielkie wspólnoty polityczne, obdarzając ich członków prawem do zachowania własnej tożsamości. Członkowie takich grup są pełnoprawnymi przedstawicielami dużej wspólnoty, ale mogą jednocześnie pozostać wierni swojej grupie etnicznej, jej dziedzictwu kulturowemu. Prawo do samorządu pozwala im zachować i rozwijać własną kulturę i tradycje polityczne. W celu stworzenia i zachowania jedności we wspólnocie federacje takie nie są nastawione na zwalczanie różnic etnicznych, kulturowych i językowych (asymilację), ale na ich zachowanie. Samoidentyfikacja wielkiej wspólnoty w tym przypadku opiera się na ścisłych relacjach i wspólnocie interesów, powszechnych i równych prawach, które jednoczą tworzące ją grupy, naród, obywateli. Federalizm pozwala członkom grup etnicznych i przedstawicielom mniejszości nie tylko zarządzać własnym życiem kulturowym, ale również zapewnia ochronę prawną, wsparcie finansowe oraz gwarantuje prawo do samorządności. Taka polityka pozwala na integrację mniejszości w większe społeczności z uwzględnieniem potrzeb gospodarczych i politycznych oraz zaspokojenie ich przez reprezentację polityczną i pomoc gospodarczą ${ }^{1}$.

W takim kontekście historycznym federalizm jest postrzegany jako mechanizm pozwalający dostosować się do różnorodności przez tworzenie wspólnych więzi łączących kilka wspólnot etniczno-kulturowych. Z tego względu federalizm zaspokaja swoiste interesy grup etniczno-kulturowych, dostarczając jednocześnie ogólnej struktury i więzi, które jednoczą te zbiorowości we wspólne dla nich państwo.

Badania konfliktów etnicznopolitycznych potwierdzają również, że wczesna, dobrze zaplanowana decentralizacja ze znacznie większym prawdopodobieństwem zapobiega separatyzmowi etnicznemu niż go wywotuje (Donald Horowitz) ${ }^{2}$. Natomiast odmowa przyznania mniejszościom autonomii terytorialnej lub decyzja o likwidacji już istniejącej autonomii (jak to miało miejsce w Kosowie i na Krymie) z reguły prowadzi do niestabilności politycznej i secesji.

W skutecznie funkcjonującym związku federalnym wiele kompetencji decyzyjnych jest zdecentralizowanych. Dlatego uważa się, że federalizm może zagwarantować sprawny system regionalnego zarządzania różnicami etnokulturowymi. W tym kontekście często wspomina się doświadczenia Szwajcarii. W tym kraju jednak prawo do samostanowienia realizują nie „etnosy”, a nawet nie grupy językowe, lecz obywatele kan-

Por. W. Kymlicka, Multicultural Citizenship. A Liberal Theory of Minority Rights, Oxford 1995, Oxford Political Theory.

А. Горовиц, Аемократия в разделенньх обществах, [w:] Демократия 1990-х. Специальньий вылуск журнала, „ГАобальные проблемы переходного периода” 1993, nr 6, s. 64. 
tonów państwa szwajcarskiego. I dlatego federacji nie tworzą cztery kantony - zgodnie z liczbą grup językowych - lecz 26 kantonów ze stosunkowo jednorodną populacją (pod względem językowej i religijnej przynależności), która jest nosicielem potrójnej tożsamości i lojalności - municypalnej (obywatel miasta), kantonalnej (obywatel kantonu Berno) i narodowej (obywatel Szwajcarii) ${ }^{3}$. Według Tove’a Malloya Szwajcaria jest systemem federalnej demokracji konsocialnej - państwem, którego podmioty sa zintegrowane poprzez wspólny jezyk i kulturę, a nie poprzez czynniki narodowościowe. Oznacza to, że kultura, jezyk i pochodzenie etniczne nie sa cechami politycznymi, które tworza narodowość. Kultura i jezyk nie podlegaja upolitycznieniút.

To oznacza, że kultura, język lub przynależność etniczna nie są właściwościami, które kształtują naród, i dlatego kultura i język nie podlegają polityzacji. Wobec wskazanych okoliczności przykład ten nie jest adekwatny w odniesieniu do naszego kraju, gdzie politycznego samookreślenia dokonywały „tytularne etnosy” (a ściślej - etnokratyczne elity), a nie obywatele.

Jednocześnie, jak zauważa wielu specjalistów, federacja jako szczególna niewiększościowa forma państwowego ustroju życia politycznego i kulturalnego spoteczeństw zróżnicowanych etnicznie okazuje się bardzo problematyczna forma ustrojowa $a^{5}$. W procesie federalizacji bowiem nieuchronnie pojawia się poważny dylemat: jak pogodzić żądania sprawiedliwości ze społeczną praktyką zapewniania szczególnych preferencji politycznych i ekonomicznych „tytularnym” grupom etnicznym.

Należy również podkreślić, że aby federalizm stat się skutecznym mechanizmem regulacji konfliktów [etnicznych - W.A.] - jak piszą John McGarry i Brendan O'Leary - jest absolutnie konieczne, aby wspólnoty etniczne byty odpowiednio rozdzielone geograficznie. Gdy wspólnoty sa zbyt rozproszone geograficznie lub mato liczne, federalizm jest mniej efektywny. Jeśli na danym terytorium grupy są zwarcie rozlokowane, federalizm jest odpowiednim mechanizmem gwarantującym autonomię grupową. Jeśli jednak grupy są przemieszane, autonomia wymaga innej niż terytorialna formy. W zależności od sytuacji demograficznej w danym państwie konieczna może okazać się kombinacja autonomii terytorialnej z nieterytorialną̧ ${ }^{6}$ W sytuacji, gdy w Federacji Rosyjskiej w 15 z 21 republik Rosjanie stanowią większość ludności lub największą liczebnie grupę etniczną, narodowo-terytorialny sposób rozwiązywania problemów etnicznych wydaje się co najmniej dyskusyjny. W ustawach zasadniczych 15 republik w latach 90. została zawarta reguła nieakceptowalna z punktu widzenia zasad demokratycznych - narzucenie większości woli mniejszości tylko na tej podstawie, że większość nie reprezentuje „tytularnej” przynależności etnicznej. W związku z tym praktycznie we wszystkich republikach narodowych ostro stawiana była „kwe-

Por. $\Lambda$. Морено, Многообразие и единство в федеративных государствах мира, „Политическая наука" 2011, nr 1, s. 163.

4 T. H. Malloy, National Minority Rights in Europe, Oxford 2005, s. 175.

5 Federalism. The Multi-ethnic Challenge, red. G. Smith, London-New York 1995, s. 3.

6 Por. J. McGarry, B. O'Leary, The Politics of Ethnic Conflict Regulation. Case Studies of Protracted Ethnic Conflict, London-New York 1993, s. 1-40. 
stia rosyjska”. Ogólną tendencją było „wypieranie” etnicznych Rosjan z kierownictwa w sferze ekonomicznej, w służbie zdrowia, w nauce i edukacji. W pełnym wymiarze dokonywał się proces „etnizacji władzy” - przedstawiciele „narodu tytularnego” stanowili i stanowią przytłaczającą większość w składzie elit politycznych w republikach narodowych ${ }^{7}$.

Ponadto, narodowo-terytorialny sposób politycznego samookreślenia wspólnot etnicznych nie jest panaceum. McGarry i O'Leary wyodrębniają osiem różnych sposobów rozwiązywania problemów „mniejszości narodowych” - od ludobójstwa i przymusowej deportacji do federalizmu i konsocjonalizmu ${ }^{8}$. Etnofederalizm wcale nie stanowi najbardziej powszechnego i optymalnego rozwiązania. Wspomniani autorzy podkreślają:federalizm jako sposób rozwiązywania konfliktów w państwach wielonarodowych i wieloetnicznych ma zta opinię nawet tam, gdzie gwarantuje mniejszościom pewien stopień samorzadności $i$.

Praktyka polityczna dowodzi, że:

1) Nie dość, że większość państw wieloetnicznych to nie federacje, to większość stanowią federacje, w których instytucjach czynnik etniczny nie znajduje odzwierciedlenia (Stany Zjednoczone, Austria, Australia, Niemcy, Meksyk, Argentyna, Brazylia, Wenezuela, Pakistan, Papua-Nowa Gwinea etc.).

2) „Mariaż” czynnika etnicznego z terytorialnym wnosi znaczący element asymetrii w konstruowaniu relacji federalnych, co najczęściej nie prowadzi do harmonii społecznej, lecz do ciągłego odtwarzania kryzysów między podmiotami „etnicznymi” i federalnym centrum, między „regionami uprzywilejowanymi” i pozbawionymi przywilejów, jak również między przedstawicielami tzw. „etnosu tytularnego” podmiotu federacji i „mniejszościami narodowymi” (Belgia, Indie, Kanada, Rosja w latach 90.). Preferencje zapewniane dowolnej mniejszości natychmiast wymagaja ochrony mniejszości w tonie tej mniejszości - Achilles nigdy nie dogoni żótwia - odnotowuje Andriej Zacharow ${ }^{10}$. Ponadto, prawa jednostki stają się pochodnymi praw wspólnot etnicznych, a te postrzegane sa jako zwarte catości („ciata zbiorowe”) z wyraźnymi granicami, wyznaczajacymi jakoby absolutnie oryginalne, samoistne i niepodobne do siebie kultury ${ }^{11}$. W rezultacie żądania grup etnicznych uznania ich prawa do politycznego samookreślenia odwołują się do prymordialnego rozumienia tożsamości etnicznej jako odwiecznej i właściwej wszystkim członkom społeczności, a terytorium samookreślenia - jako miejsca, gdzie dokonata się etnogeneza danego narodu (Swietłana

Por. Р. Галмямов, Политические элиты российскихреспублик: особенности трансформации в постсоветский период, [w:] Трансформация российских региональных элит в сравнительной перспективе, red. А. Мельвиль, Москва 1999, s. 163-174 i nast.

8 Por. J. McGarry, B. O'Leary, Explaining Northern Ireland. Broken Images, Oxford-Cambridge (Mass.) 1995.

9 Por. J. McGarry, B. O'Leary, The Politics of Ethnic Conflict Regulation..., s. 111-112.

10 А. Захаров, „Спящий институт”: Федерализм в современной России и мире, Москва 2012, s. 69.

11 В. Шнирельман, „Патриотическое воспитание”: этнические конфликты и икольные учебники истории, [w:] Расизм в языке образования, red. В. Воронков, О. Карпенко, А. Осипов, Санкт-Петербург 2008, s. 90. 
Czerwonnaja) ${ }^{12}$. Jednakże zarówno społeczne i terytorialne granice grup etnicznych, jak też ich tożsamość mogą zmieniać się w czasie (dlatego kwestia pierwotnych terytoriów tego czy innego „rdzennego etnosu” nie ma rozstrzygnięcia). Etnofederalizm natomiast instytucjonalizuje to, co może być tymczasową tożsamością „etniczną", jako formę niezmienną, utrwalając w ten sposób istniejące różnice i przyczyniając się do ich odtwarzania w zmienionych warunkach identyfikacji, interakcji kulturowej i hybrydyzacji kultury. Ponadto, w społeczeństwach, w których etniczność jest terytorializowana (tzn. zostaje ustalony ścisły związek między wspólnotą etniczną i zajmowanym przez jej członków terytorium) i upolityczniona, każda wątpliwość co do legitymizacji istniejacych instytucji natychmiast ttumaczona jest na jezyk redystrybucji terytorialnej i podziatu zasobów oraz postrzegane sa przez dominujaca spoteczność jako zagrożenie. Terytorializacja etniczności, podziat spoteczeństwa na naptywowych i rdzennych, swoich i obcych, oprócz eskalacji konfliktów spotecznych prowadzi do pojawienia się $w$ dyskursie politycznym (a poprzez to również w prawodawstwie) motywów polityki asymilacji lub czystek etnicznych. Prawa zbiorowe, które otrzymuja teoretyczne "podmioty zbiorowe" ("etnosy”, "narody”), implikuja prawny korelat odpowiedzialności zbiorowej, co w historii panstwa radzieckiego stanowito koncepcyjne uzasadnienie deportacji i ludobójstwa $a^{13}$.

3) Federalizm tworzy podatny grunt dla pojawienia się dużej liczby aktorów zdolnych do prowadzenia własnej gry politycznej, często sprzecznej z interesami centrum federalnego (w Rosji próbowano zneutralizować to potencjalne niebezpieczeństwo poprzez zakaz tworzenia partii regionalnych i etnicznych). Jednak niebezpieczna jest także odwrotna sytuacja - gdy centralizacja systemu partyjnego jest tak silna, że partie przestają reprezentować interesy podmiotów federacji, co również może sprzyjać konfliktom na linii centrum federalne - regiony, co jest szczególnie niebezpieczne dla etnofederacji.

4) W warunkach transformacji społecznych etnofederalizm tworzy dodatkowy potencjał konfliktowy. Przywiazanie do federalizmu czessto wyczerpuje się, gdy wymaga on od nich [podmiotów federacji - W.A.] dodatkowej pracy i naktadów finansowych z przekąsem zauważa Charlie Jeffery ${ }^{14}$.

Znana amerykańska politolog Valerie Bunce wręcz deklaruje: nie uważam, że etnofederalizm to dobry system. W przypadku przechodzenia panstwa od autorytarnego systemu rzadów do liberalnego - a temu zawsze towarzyszy ostabienie wtadzy centralnej - taki system nieuchronnie prowadzi do rozpadu państwa, a czasami także do wojny ${ }^{15}$.

Poza tym federalizm nie jest stanem niezmiennym, to proces stawiający bardzo wysokie wymagania zarówno elitom politycznym, jak i obywatelom. Jak pisał jeszcze na

12 С. М. Червонная, Абхазия-1992: посткоммунистическал Вандея, Москва 1993, s. 59.

13 С. Соколовский, Перспективы развития конщепиии этнонациональной политики в Российской Федераиии, Москва 2004, s. 28.

14 Ch. Jeffery, The Non-Reform of the German Federal System after Unification, „West European Politics” 1995, Vol. 18, s. 264.

15 В. Банс, „Поздно сбросили” (Интервью Валерии Банс журналу „Эксперт”, nr 11 (505) от 20.03.2006), [w:] Русские чтения, wуd. 3, Москва 2006, s. 93. 
początku XX w. znany rosyjski prawoznawca Aleksandr Jaszczenko: [...] System federacyjny w petni oparty na umowach, na wzajemnych ustępstwach, jest bardzo kruchy, niestabilny i staby; dla mniej lub bardziej normalnego funkcjonowania wymaga nadzwyczajnego ducha praworzadności oraz przyzwyczajenia zbiorowości do podporzadkowania się prawu, a w szczególności decyzjom bezstronnego i niezawistego sądu, rozwiązującego konflikty między wtadzami centralnymi i lokalnymi ${ }^{16}$.

W odniesieniu do wymogów zapewnienia samorządności terytorialnej i politycznej mniejszościom narodowym sytuacja jest jeszcze bardziej skomplikowana, ponieważ wymogi te zaktadaja budowe specjalnych instytucji i wzmocnienie odrębnej tożsamości narodowej - wskazuje Will Kymlicka. $Z$ tego względu tworza one zjawisko konkurujących nacjonalizmów w jednym państwie. Nauczyć się tym rządzić to bardzo trudne zadanie ${ }^{17}$.

W latach 90., kiedy federalna władza wykonawcza była słaba i potrzebowała wsparcia politycznego ze strony regionalnych elit politycznych, Rosja nieustannie balansowała na krawędzi rozpadu, przede wszystkim w wyniku niekończącego się nieformalnego targu z republikami narodowymi w sprawie nowego podziału władzy i środków finansowych. Jednak brak instytucjonalizacji tych pertraktacji, czyli brak jasnych zasad co do tego, co i jak może być omawiane, przekształcił je w niekończące się dyskusje, podczas których teoretycznie można było podać w wątpliwość każdy aspekt projektu federalnego $-\mathrm{z}$ celowością istnienia związku włącznie ${ }^{18}$.

Aby oddać sprawiedliwość, należy zauważyć, że w rzeczywistości żaden z regionów, z wyjątkiem Czeczenii, nie chciał rzeczywistej secesji. Dlatego stwierdzenie Władimira Putina, że pod koniec lat 90. kraj sięrozpadat ifaktycznie byt w stanie wojny domowej, to, najoględniej mówiąc, przesada. Jednak, jak pisał Daniel Treisman: Konstytucja pozostawita nierozwiazanymi wiele $z$ najważniejszych zagadnień $w$ relacjach regionów $z$ centrum federalnym i niemal natychmiast po jej wejściu $w$ życie rozpocząt sie proces negocjacji, który doprowadzit do podpisania umów dwustronnych, dotyczacych podziatu kompetencji ${ }^{19}$. Według danych Leonida Iwanczenki zawarto 46 dwustronnych umów i około 300 porozumień (liczba robi wrażenie), nadających podmiotom Federacji (a przede wszystkim republikom narodowym) różnego rodzaju przywileje ekonomiczne i finansowe, co z kolei wzmacniało ich polityczną niezależność od centrum ${ }^{20}$. Podmioty Federacji de facto zostały podzielone na trzy kategorie: 1) regiony, które otrzymały na mocy umów z centrum uprzywilejowaną pozycję

16 Суt. za: $\Lambda$. Карапетян, Федерализм и права народов. Курс лекиий, Москва 1999, s. 17-18.

17 У. Кимлика, Современная политическал философия. Введение, Москва 2010, s. 466, Политическал meopus.

18 M. Filippov, P. Ordeshook, O. Shvetsova, Designing Federalism. A Theory of Self-Sustainable Federal Institutions, Cambridge 2004, s. 92.

19 D. Treisman, After the Deluge. Regional Crises and Political Consolidation in Russia, Ann Arbor 1999, s. 26.

20 Pог. $\Lambda$. Иванченко, Организационно-правовое обеспечение приоритетов регионального развития, [w:] Конститущионно-правовые проблемь развития российского федерализма, red. А. Иванченко, В. Калита, Москва 2000. 
(Tatarstan, Baszkortostan, Jakucja); 2) regiony, z którymi zostały zawarte umowy dwustronne (ponad 40); 3) regiony, które nie uregulowały swoich stosunków z centrum (około 40).

Przyjęcie w 1995 r. ustawy „O trybie powoływania Rady Federacji Zgromadzenia Federalnego Federacji Rosyjskiej” („О порядке формирования Совета Федерации Федерального Собрания Российской Федерации”), zakładającej tworzenie wyższej izby parlamentu z wybranych przedstawicieli władzy ustawodawczej i wykonawczej podmiotów federacji, zmusiło centrum do rezygnacji z wyznaczania zwierzchników regionów. Od jesieni 1996 r. zwierzchnicy wszystkich podmiotów Federacji Rosyjskiej byli wybierani bezpośrednio przez mieszkańców. Doprowadziło to do tego, że regionalni liderzy zyskali demokratyczną legitymizację i stali się petnoprawnymi przywódcami, niezależnymi od polityki personalnej centrum ${ }^{21}$. Dlatego gubernatorzy musieli zbudować nowe relacje z centrum. Kluczowym elementem relacji dwustronnych stał się interes regionalny, deklarowany jako interes całej społeczności regionalnej. Przywódcy podmiotów federacji zajmowali pozycję rzeczników interesów wszystkich mieszkańców regionu, dlatego często dochodziło do otwartej konfrontacji między nimi a centrum federalnym. Najostrzejszą formę konflikty przybierały podczas kryzysów (np. w sierpniu 1998 r.), gdy regiony zostały zmuszone do radzenia sobie na własną rękę z ich konsekwencjami. Walka o interesy regionalne toczyła się przede wszystkim w Radzie Federacji, która blokowała ustawy naruszające prawa podmiotów federacji.

Ogólnie rzecz biorąc, stosunki na linii centrum-regiony w latach 90. kształtowaty się na zasadzie konstytuowania negocjowalnej federacji „asymetrycznej” (a nie konstytucyjnej). Zapewnienie (faktycznego) priorytetu prawodawstwa podmiotów federacji w odniesieniu do ustawodawstwa federalnego de facto zmienito Federacje Rosyjska w lużna konfederacje. Prezydent Rosji, publicznie nawotujacy do zachowania integralności terytorialnej kraju i wzmocnienia rosyjskiej państwowości, w okresach najbardziej ostrych kryzysów politycznych apelowat przede wszystkim do etnopolitycznych elit republik narodowych, ptacac za ich wsparcie "przekazywaniem regionom" coraz szerszych praw i petnomocnictw, wzmacniając tym samym odśrodkowe dązenia "suwerennych państw narodowych" w sktadzie Federacji Rosyjskiej22.

Z kolei w republikach narodowych - „lokomotywach suwerenizacji” - główną ideą, wokół której budowano tożsamość regionalną na przełomie lat 80. i 90., była idea odrodzenia etnicznego. Tak np. w Tatarstanie, jak zaznacza Lilia Sagitowa, nawet tematy niezwiazane bezpośrednio z pochodzeniem etnicznym byty omawiane w świetle tych problemów. W praktyce dyskursywnej elit republikańskich problemy narodu tatarskiego wiązano zarówno z polityką państwa rosyjskiego, jak i w dużej mierze z etniczną większością rosyjską, która wzmacniała opozycję (ro-

21 В. Гельман, Региональная власть в современной России: институты, режимь и практики, „Полис" 1998, nr 1, s. 100.

22 В. Филиппов, Кризис этнического федерализма в России, [w:] Регионы и регионализм в странах Запада и России, red. Р. Иванов, Москва 2001, s. 184. 
syjskie) państwo - republika (Tatarstan) ${ }^{23}$. Tatarzy jawili się jako „ofiary” rosyjskich "uzurpatorów”.

Nie mniej ważną rolę w polityce tożsamości w Tatarstanie odgrywał temat państwowości, która była postrzegana jako konieczny warunek kulturowego i językowego odrodzenia Tatarów. W związku z tym poruszano m.in. problemy obowiązkowej nauki języka tatarskiego w szkołach i kształcenia w języku tatarskim w szkołach wyższych. Państwowość była postrzegana przez elity polityczne Tatarstanu jako możliwość redystrybucji władzy i własności w republice. Republikańscy aktorzy z dużym powodzeniem „targowali się” o możliwość prowadzenia niezależnej polityki, w tym zagranicznej, w zamian za zrzeczenie się dążeń do separacji od Rosji. Ekskluzywizm polityki tożsamości legitymizował zasadność takich działań, zarówno w oczach Moskwy, jak i wewnątrz republiki.

Podobne procesy postępowały również w innych republikach narodowych Federacji Rosyjskiej, w których elity polityczne zaczęly aktywnie rozgrywać kartę etniczną w relacjach z Moskwą. Innymi słowy, polityka tożsamości stała się dla elit republikańskich najbardziej odpowiednim narzędziem w walce $\mathrm{z}$ "centrum” o udział w zyskach z eksploatacji zasobów naturalnych i kontrolę nad regionem, podczas gdy czynnik etniczny w dużej mierze służył jako czynnik $i$ instrument konsolidacji ludności republiki wokót jej liderów ${ }^{24}$. W rezultacie pierwszy prezydent Federacji Rosyjskiej Borys Jelcyn pozostawił w spadku „następcy” osłabiony, niezinstytucjonalizowany system polityczny, zdeformowaną pionową strukturę władzy, kryzys legitymizacji, nieskonsolidowaną, źle zarządzaną i mocno skorumpowaną elitę rządzącą.

Przekształcenie Rosji w pierwszej dekadzie XXI w. w „wielkie mocarstwo energetyczne” oraz związany z tym nadmiar "łatwych” pieniędzy będących w dyspozycji państwa uwarunkował wybór strategii monopolizacji i niekonkurencyjnego trybu dystrybucji zysków z eksploatacji złóż naturalnych przez centrum federalne. Dlatego też wahadło wychyliło się w przeciwnym kierunku. W wyniku tego zbudowano pionową strukturę władzy, w ramach której centrum federalne, radykalnie ograniczając zakres autonomii regionalnej, nie tylko scentralizowato system federalny, ale w rzeczywistości postawito pod znakiem zapytania jego istnienie ${ }^{25}$.

Przede wszystkim radykalnie zmieniły się „reguły gry” między centrum i regionami. Wyraźnym wskaźnikiem tego stanu rzeczy była redystrybucja środków budżetowych, w wyniku czego do regionów trafiata (wbrew prawu) już nie potowa, lecz nieco więcej niż jedna trzecia środków. Podziat ten uzasadniany byt koniecznościa zapewnienia pomocy dotowanym regionom. Skutkiem tego automatycznie zmniejszata się liczba regionów Federacji dotujacych i zwiększyta - dotowanych, zostata przy tym ograniczona inicjatywa i samodzielność regionów w rozwiąywaniu problemów lokalnych [...], wzmacniana jest

23 А. Сагитова, Региональная идентичность: сочиальнье детерминанты и конструктивистская деятельность СМИ (на примере Республики Татарстан), [w:] Центр и региональные идентичности в России, red. В. Гельман, Т. Хопф, Санкт-Петербург 2003, s. 95-96.

24 Tamże, s. 98.

25 Н. Панкевич, Модели федеративного устройства. Закономерности политической трансформащии, Екатеринбург 2008, s. 177. 
sktonność do pozostawania na statym utrzymaniu, co stoi w wyraźnej sprzeczności z ogólnoświatowymi trendami decentralizacyjnymi ${ }^{26}$.

W rezultacie wbrew duchowi i literze Konstytucji centrum federalne zmonopolizowato funkcje regulacyjne, pozostawiając regionom tylko wykonawcze. [...] Polityczne ryzyko niespetnienia zobowiązań wobec spoteczeństwa (również) zostato przekazane na dót - reasumuje Michaił Afanasjew ${ }^{27}$.

Po utworzeniu siedmiu okręgów federalnych i zmianie sposobu powoływania Izby Wyższej Zgromadzenia Federalnego Federacji Rosyjskiej, najbardziej zauważalną inicjatywą Prezydenta była zmiana procedury obsadzania stanowisk zwierzchników władzy wykonawczej podmiotów federacji. Od jesieni 2004 r. wybory szefów władz wykonawczych regionów przestały być powszechne, a gubernatorzy wybierani byli przez legislatury podmiotów federacji spośród kandydatów rekomendowanych przez Prezydenta i jego pełnomocnych przedstawicieli. W rzeczywistości oznaczało to zmniejszenie niezależności podmiotów Federacji Rosyjskiej, ponieważ Prezydent, oprócz zgłaszania kandydatów, miał prawo dymisjonować gubernatorów, którzy „zawinili”. Mieszkańcy regionów mieli jedynie prawo wyboru deputowanych do ustawodawczego organu władzy, co zaszkodziło autonomii nie tylko podmiotów federacji, ale również kształtujących się w ich granicach wspólnot regionalnych.

Wydawać by się mogło, że w rezultacie stworzono jednolity system administracyjny, dziatający jak jeden organizm ${ }^{28}$. Jednak okazało się, że reformy centralizacyjne miały niejednoznaczne i niejednakowe skutki dla różnych podmiotów Federacji Rosyjskiej, zwłaszcza dla republik narodowych. Liczne preferencje podatkowe i finansowe zachował np. Tatarstan. Według Natalii Zubarewicz Tatarstan w zamian za lojalność otrzymuje za pośrednictwem różnych kanatów ogromne dodatkowe fundusze z budżetu federalnego na realizację wielu programów inwestycyjnych ${ }^{29}$.

Z kolei system rządów powstały w republikach Kaukazu Północnego, jak sądzi Lilia Szewcowa, przyjąt skrajny autorytarno-klanowy charakter $i$ zasadza sie na federalnych bagnetach i dotacjach. Moskwa okazata się zaktadnikiem lokalnych watazkków, takich jak Ramzan Kadyrow [...], którzy zrzucając cata odpowiedzialność na centrum, tylko wzmacniaja nastroje antyrosyjskie $w$ regionie ${ }^{30}$. Niestety prawdziwość tej tezy wyrażonej dziewięć lat temu potwierdzają wydarzenia w Inguszetii, Dagestanie, a także w innych republikach Kaukazu Północnego. Niemniej jednak, rosyjscy politycy wola ignorować stopniowe przeksztatcanie regionu $w$ „wewnętrzna zagranice”" [...]. Pomimo że kaukaskie

26 К. Холодковский, Самоопределение России, Москва 2013, s. 158.

М. Афанасьев, Невынносимая слабость государства, Москва 2006, s. 262, 266.

Выступление президента РФ В. В. Путина на заседании Правительства РФ с участием глав региональныц администрачий. Москва 13 сентября 2004 г., [online] http://kremlin.ru/text/ appears/2004/09/76651.shtml, 15 VI 2012.

29 Н. Зубаревич, Сочиоэкономические различия между этническими регионами и политика перераспределения, [w:] Федерализм и этническое разнообразие в России, red. И. Бусыгина, А. Хайнеманн-Грюдер, Москва 2010, s. 91.

30 А. Шевцова, Россия - год 2006: логика политического страха, сz. 2, „Независимая газета” 2005, 16 XII. 
elity postrzegaja siebie jako części Rosji i sa kategorycznie przeciwne separatyzmowi, jednocześnie wola jednak kierować się „kaukaskim prawem”, które opiera się na klanowym $i w$ dużym stopniu tradycyjnym charakterze spoteczeństwa $i$ znaczacej roli islamu - zauważa Aleksiej Małaszenko ${ }^{31}$.

Nie ma wątpliwości, że islamizacja i powrót do tradycji szeregu republik narodowych Rosji jest swoistą odpowiedzią na ideologiczną i polityczną bezpłodność elity „nowej” Rosji. Jest to reakcja na niezdolność państwa do wygenerowania ogólnonarodowej idei i światopogladu. Dokarmiając rządzace klany regionów muzutmańskich $w$ rewanżu za ich lojalność polityczna, Kreml ignorowat ludność tych regionów. W reakcji na poziomie lokalnym mieszkańcy często jednocza się wokót radykalnej awangardy - islamskich liderów, którzy sa bardziej przekonujacy w formutowaniu swojej "prawdy”. Jest to $w$ dużej mierze odpowied 'z $z$ dotu” wobec skorumpowanej i niesprawnej wtadzy centrum i regionów. Pozbawienie mniejszości narodowych kanatów awansu spotecznego i politycznej reprezentacji ich interesów w skali ogólnorosyjskiej, a także spychanie ich na margines wspótczesnych procesów edukacyjnych i informacyjnych doprowadzito do wzrostu religijności islamskiej jako formy samoobrony ${ }^{32}$.

Wciągnięcie w sferę wpływu islamu znacznej części młodzieży z republik Kaukazu Północnego doprowadziło do tego, że młode pokolenie coraz częściej uważa się za członków światowej islamskiej ummy i coraz rzadziej identyfikuje się z Rosją. W związku z tym, że Kaukaz Północny i szereg republik Powołża są częścią świata islamskiego, można oczekiwać pojawienia się na ich terytorium tych samych ruchów religijno-politycznych, które w arabskiej części świata islamskiego usiłują dziś urzeczywistniać radykalne transformacje. Dlatego obecne kierownictwo Rosji powinno uwzględniać te procesy globalne, a w szczególności nieuchronność dalszej radykalizacji islamu i jego ekstremistycznych przejawów (Aleksiej Małaszenko) ${ }^{33}$.

Dziś większość badaczy charakteryzuje rosyjski federalizm jako „pustą formę” (Nikołaj Pietrow), „quasi-federalizm” (Rostisław Turowskij), „federację bez federalizmu” (Cameron Ross), „instytucję uśpioną” (Andriej Zacharow) etc.

Nowej Rosji wystarczyty zaledwie dwie dekady, aby przeksztatcić tak inspirujace dla naszych mniejszości struktury federalne, odnowione na początku lat 90. w typowy uktad imperialny z wtaściwa mu wymiana lojalności wobec Kremla na szeroka swobodę dziatania we wtasnym folwarku - zauważa Zacharow ${ }^{34}$.

Według niektórych ekspertów ten wahadłowy charakter relacji na linii centrum federalne - regiony uwarunkowany jest tym, że w Rosji federalizm nie jest formą samoorganizacji obywatelskiej, lecz zostaje wprowadzony i wykorzystany jako technologia dys-

31 А. Малашенко, Новый президент и „старый” Северньй Кавказ, [w:] Повестка дня нового президентства, red. М. Аипман, Москва 2012, s. 56-57, Pro et Contra.

32 А. Магомедов, Российский правящий класс и „исламскал альтернатива”: к новому осмыслению политического, [w:] Власть и элитьь в российской трансформачии, red. А. Аука, Санкт-Петербург 2005.

33 А. Макашенко, Новъцй президент и „старый...., s. 58.

34 А. Захаров, „Спящий институт”. Федерализм в современной России и в мире, Москва 2012, s. 114 , Библиотека журнала „Неприкосновенный Запас". 
trybucji (i podziatu) wtadzy (przy braku wskazania realnych celów). Dla elity rządzacej [...] federalizm jest pojęciem czysto instrumentalnym, pozbawionym tadunku wartości $i^{35}$. Jednakże spetnianie podstawowych standardów federalistycznych $w$ rozumieniu aksjologicznym wymaga instytucjonalizacji federalizmu jako systemu prawnego i praktyki politycznej, wsparcia przez rozwiniętą kulturę demokratyczną, instytucje społeczeństwa obywatelskiego $^{36}$.

Elity republik narodowych, które w latach 90. były „lokomotywami suwerenizacji”, w istocie, otrzymały od Kremla rodzaj „listu żelaznego”. Nie straciły apetytu na władzę i na jej nieformalną redystrybucję na swoją korzyść, oczywiście „w imię interesów swojego narodu". W pierwszej dekadzie XXI wieku centrum udato się zatatać pieniędzmi z budżetu wszystkie istotne problemy finansowe i gospodarcze w regionach przekonuje Andriej Starodubcew. - Jednocześnie stopniowe ograniczenie pola, na którym może przejawić się protest publiczny, zabezpieczyto pozór jedności kraju ${ }^{37}$. Jednak jeśli cata odpowiedzialność za rozwój regionów i dobrobyt ludności spoczywa na centrum federacji, a na to, co spoczywa "na barkach" wtadz lokalnych, nie przewidziano środków finansowych (pozostaje tylko 30\% środków z ogótu środków wnoszonych przez podmioty federacji), to niezadowolenie ludności i elit regionalnych jest kierowane do rzadu centralnego - zauważa Leokadia Drobiżewa ${ }^{38}$. W związku z tym w warunkach poważnych konfliktów gospodarczych może ponownie pojawić się silna motywacja do poszukiwania sposobów osłabienia centrum poprzez nieformalną redystrybucję władzy i zasobów, a nawet chęć „ratowania się w pojedynkę”. Z tego względu może znów pojawić się zagrożenie rozpadu Rosji, które i tym razem najprawdopodobniej będzie miało swoje źródło w republikach narodowych. Według Andrieja Zacharowa:federalizm nie na dtugo pozostanie instytucja uśpiona: odwilż polityczna staje się coraz bardziej nieunikniona $w$ miare powolnego, nieuchronnego bankructwa systemu opartego na obfitości ropy naftowej i wkrótce na federalizm znów pojawi się duże zapotrzebowanie ${ }^{39}$. Problem polega jednak na tym, jakie cele będą realizować w nowej sytuacji elity centralne i regionalne.

W związku z tym oparta na etnofederalizmie polityczna autonomia terytorialna grup etnicznych najczęściej staje się źródłem konfliktów, a nie sposobem ich rozwiązania. Szczególnie w sytuacji, gdy na zachowaniu różnic skupia się zbyt wiele uwagi ze szkoda dla celowego ksztattowania tych tradycji, wartości i nadziei, które sa wspólne dla różnych ludzi, co może prowadzić do dalszej fragmentacji spoteczeństwa i ostabienia poczucia solidarności. Akceptując różnice kulturowe oraz swoistość etniczno-wyznaniowa,

35 М. Миронюк, Современный федерализм. Сравнительньй анализ, Москва 2008, s. 103.

36 Por. А. Захаров, E pluribus ипит. Очерки современного федерализма, Москва 2003, s. 38-58, Библиотека Московской икольь политических исследований.

37 А. Стародубцев, Бесполезное достижение? Губернаторские выьбры в контексте проблем регионального развития, „Неприкосновенный запас” 2012, $\mathrm{nr} 4$, s. 89.

$38 \Lambda$. Аробижева, Этничность в сочиально-политическом пространстве Российской Федерации. Опьит 20 лет, Москва 2013, s. 166.

39 А. Захаров, „Спящий институт”: Федерализм в современной России и в мире, Москва 2012, s. 124. 
należy potożyć nacisk na wartości ogólnonarodowe i chronić prawa wszystkich obywateli. W zwiazku z tym, jednym z gtównych problemów [szczególnie w dzisiejszej Rosji W.A.] jest kwestia zdolności federalizmu do moderowania relacji między etnosami, z poszanowaniem ducha i litery demokracji liberalnej ${ }^{40}$.

Międzynarodowe doświadczenie pokazuje, że po pierwsze, przykłady dobrze funkcjonujących federacji etnicznych są rzadkie, a większość prób ich stworzenia okazała się nieudana; po drugie, rozwiązując „problemy etniczne”, najlepiej funkcjonujące demokracje wieloetniczne często nie zmierzają ku tworzeniu federacji etnicznych, lecz wybierają drogę „odprzedmiotowienia” i depolityzacji czynnika etnicznego w ramach polityki wielokulturowości, drogę demontażu instytucji łączących etniczność z władzą, etniczność z państwem, co jest osiągane poprzez podkreślanie procesualnego charakteru etniczności, wielości tożsamości społecznych i idei „narodu obywatelskiego”, a to z kolei nie pozwala uznać etnofederalizmu za optymalny sposób rozwiązywania problemów etnicznych $\mathrm{w}$ „,wieloetnicznym” państwie.

Co więcej, nikt w naszej ojczyźnie nie zastanawia się nawet, na ile poprawne jest rozpatrywanie takiej umownej zbiorowości jak naród czy mniejszość narodowa w roli podmiotu prawa - czy taka wspólnota ma cechy podmiotu prawa? Podmiot prawa nie tylko powinien posiadać zdolność do nabywania i realizowania swoich praw poprzez swoje dziatania, ale także wypetniać zobowiązania i ponosić odpowiedzialność. Umowna lub statystyczna zbiorowość takich wtaściwości nie posiada, można mówić jedynie o fikcjí ${ }^{41}$ bądź o pewnego rodzaju „megaanthroposie”, w którego imieniu działają elity etnokratyczne.

Kształtowanie radzieckiej federacji i jej spadkobierczyni Federacji Rosyjskiej w oparciu o tzw. zasadę narodowo-terytorialną, którą w republikach narodowych także obecnie nazywa się „wielkim kompromisem”, doprowadziło do tego, że obywatele różnego pochodzenia etnicznego faktycznie uzyskali nierówny status prawny oraz nierówne prawa i warunki do samorealizacji, zachowania i rozwoju swojej odrębności kulturowej. Jest to spowodowane m.in. tym, że mniej niż połowa przedstawicieli narodów nierosyjskich mieszka w granicach podmiotów narodowo-prawnych i więcej niż połowa ludności tych podmiotów (republik i okręgów autonomicznych) to tzw. ludność „nietytular-

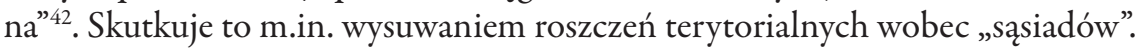

Nadanie „etnosom” prawa do samorządu politycznego generuje cały szereg pytań, na które nie ma odpowiedzi w ramach federacji narodowo-terytorialnych: Jeśli określo-

40 Г. Грибанова, А. Сидоренко, Федерализм и разрешение этнополитических конфликтов в современном обществе, „Политэкс. Политическая экспертиза” 2007, Vol. 3, nr 3, s. 21.

41 А. Осипов, Эссенциалистские представления об этничности в системах преподавания правовьц специальностей, [w:] Расизм в языке образования, red. В. Воронков, О. Карпенко, А. Осипова, Санкт-Петербург 2008, s. 147.

42 Według wyników spisu ludności z 2002 r. największy procentowy udział tzw. „narodu tytularnego” odnotowano w Republice Czeczeni - 93,5\%. Do republik, gdzie składowa przedstawicieli narodu tytularnego wynosiła ponad 50\%, należą: Tuwa, Inguszetia, Czuwaszja, Osetia Północna (Alania), Kałmucja, Kabardyno-Bałkaria i Dagestan (z uwzględnieniem wszystkich „rdzennych” narodowości). Najmniejszy udział procentowy przedstawicieli narodu tytularnego odnotowano w Karelii (9\%) i Chakasji (12\%). 
ny podmiot federacji „należy” do „narodowości tytularnej”, to, czy wynika z tego, że nie jest „swoim" dla pozostatych zamieszkujacych tam obywateli? Jak więc zinterpretować to, że oni ptaca podatki, biora udziat w wyborach i ciesza się petnia praw obywatela i cztowieka? Jeśli państwowość jest dla nich także „swoja”, to, po co deklaracje jej etnicznej „przynależności"? Jeśli takie wypowiedzi maja nie tylko symboliczne znaczenie, to w czym, w jakich instytucjach i relacjach znajduje odzwierciedlenie ten zwiazek między etnicznościa i terytorium? ${ }^{43}$

Nieprzypadkowo wielu badaczy pisze o braku związku między praktyką wielu federacji etnicznych i realizacją wartości liberalnych. Dlatego system federalny, by nie przerodzić się w nieformalny sojusz etnokracji, musi stworzyć preferencje nie tylko dla mniejszości etnicznych, ale też politycznych, albowiem [...] ograniczenie jego wptywów wytacznie do relacji etnicznych pozwala catkowicie w topić osobę w kolektywna catość, ponieważ prawa i wolności przypisuje w pierwszym rzędzie grupie etnicznej, a dopiero potem-jednostce ${ }^{44}$.

Nasuwa się oczywisty dla wielu badaczy rosyjskich wniosek: Żadna, nawet najbardziej radykalna suwerenizacja "narodowych" podmiotów Federacji Rosyjskiej i narodów niemajacych na jej terytorium narodowo-panstwowych formacji nie rozwiąze problemów zwiazanych z ochrona interesów etnicznych zamieszkujacych ja obywateli. W zwiazku z tym, wyjścia z obecnej sytuacji należy szukać w transformacji Rosji w federację terytorialna $a^{45}$. Jednakże pojawia się trudna kwestia znalezienia najmniej „kosztownej" i konfliktowej drogi przeprowadzenia tego rodzaju radykalnej reformy rosyjskiego federalizmu.

Rola instytucji etnofederalizmu w tworzeniu i odtwarzaniu rzeczywistości etnicznej jest tak samo ważna i znacząca dla dużej części rosyjskich „narodowości”, jak indywidualna przynależność do grupy etnicznej (nieprzypadkowo właśnie w republikach narodowych tak aktywnie protestowano przeciwko zniesieniu piątej rubryki w paszporcie, gdzie podawano informację o narodowości). W związku z tym, że tożsamość etniczna, oprócz tego, że stanowita kryterium klasyfikacji i podziatu populacji kraju na poszczególne i mające odmienny status prawny kategorie, byta również sposobem podziatu i strukturyzowania przestrzeni administracyjnej i politycznej ${ }^{46}$.

Sformułowane już propozycje stworzenia równych pod względem prawnym i ekonomicznym podmiotów federacji, rozwijających się w tym samym tempie i stopniowej symetryzacji struktury federalnej ${ }^{47}$ lub zupełnej rezygnacji z federalizmu (Władimir Żyrinowskij) - mogą być zatem postrzegane jako najmniej prawdopodobna perspektywa dla Rosji.

43 А. Осипов, Эссенщиалистские представления..., s. 150-151.

44 А. Захаров, „Спящий институт”..., s. 96.

45 Народовластие в России - очерк истории и современного состояния, red. Ю. Амитриев, Москва 1997, s. 57.

46 С. Соколовский, Перспективы развития..., s. 60-61.

47 Por. Аоктринарегионального развития Российской Федерачии: Мини проект, red. С. С. Сулакшин i in., Москва 2009, s. 92. 
Dziś przywódcy polityczni Rosji demonstrują optymizm i wiarę w świetlaną przyszłość naszego kraju. Jednak dla wszystkich jest oczywiste, że czekają nas niełatwe czasy, co oznacza, że jest możliwy także nowy cykl dezintegracji rosyjskiego terytorium, mający swe źródło we względach etnicznych. Symptomy tego zjawiska są już zauważalne, według niektórych danych zwiększony poziom lęku widoczny jest w $65 \%$ populacji Rosjan, podczas gdy przeciętna to $10-15 \%{ }^{48}$. Z kolei, zgodnie z danymi Sieci Monitoringu Etnologicznego EAWARN, od drugiej potowy minionej dekady w catej przestrzeni postradzieckiej, zarówno w sferze politycznej, jak i międzyetnicznej widoczna jest tendencja do wzrostu napięcia ${ }^{49}$.

Całkiem rozsądnie zauważył w swoim przedwyborczym artykule Władimir Putin: Pokój spoteczny i porozumienie między narodami - to nie obraz raz ustanowionej i na wieki utrwalonej sytuacji. Przeciwnie - to nieustanna dynamika i dialog. To żmudna praca państwa $i$ spoteczeństwa, wymagajaca bardzo subtelnych decyzji, wyważonej i madrej polityki, zdolnej zapewnić „jedność w różnorodności". Konieczne jest nie tylko przestrzeganie wzajemnych zobowiazań, ale także znalezienie wspólnych dla wszystkich wartości. Nie można zmusićsita do bycia razem. Inie można zmusić do życia razem zrozsądku, ważac korzyści i straty. Takie „kalkulacje” dziataja tylko do momentu kryzysu. A w chwili kryzysu zaczynaja dziatać wodwrotnym kierunku ${ }^{50}$. Lecz nie ma pewności, że możemy zapewnić harmonijny rozwój wielokulturowej spoteczności, w oparciu o nasza kulture, historię i typ tożsamości ${ }^{51}$.

Już dziś komunikacja, relacje gospodarcze i częściowo nawet kulturalne [...] Primorja z Chinami, enklawy kaliningradzkiej z Unia Europejska, Kaukazu Pótnocnego z Turcją $i$ arabskimi wahabitami, Karelii - $z$ Finlandia [...] sq $w$ przybliżeniu równe lub nawet silniejsze niż związki tych regionów z Moskwa i reszta Rosji. Wtadza centralna dostrzega te problemy, ale stara się starym „radzieckim” zwyczajem rozwiązywać je poprzez „wzmocnienie pionowego systemu zależności", budżetowa smycz, coraz to nowe zakazy i oficjalna retorykę o „wielkości" $i$,jedności” - konstatuje Nikołaj Rozow ${ }^{52}$.

Dziś współistnieje równolegle jakby „kilka Rosji” z ich sposobem życia, wartościami, modelami zachowania, własnymi interesami i nadziejami na przyszłość. Nieprzypadkowo szeroką popularność, mimo swej metaforyczności i socjologicznej niepoprawności, zyskała hipoteza Natalii Zubarewicz o „czterech Rosjach”, które funkcjonują obecnie i faktycznie nie stykają się ze sobą ${ }^{53}$.

Istnienie tego typu rozłamów w kraju potwierdza praktyka polityczna. Już dzisiaj rosyjscy nacjonaliści starający się spekulować nadszarpniętym poczuciem sprawiedli-

48 В. Каган, Ното Хеnophobicus: психология „своего и чужого”, „Национальный психологический журнал" 2011, nr 2 (6), s. 43.

49 В. Степанов, Рейтинг конфликтности государств и регионов по данным Сети этнологического мониторинга за 2010 год, [w:] Этнополитическал ситуация в России и сопредельньцх государствах. Ежегодный доклад, red. В. Тишков, В. Степанов, Москва 2011, s. 244.

В. В. Путин, Россия: Национальныцй вопрос, „Независимая газета” 2012, 23 I.

51 Tamże.

52 Н. С. Розов, Теории исторической динамики Рэндалла Колиинза и контексте российской политики, „Полис" 2012, nr 6, s. 129-130.

53 Н. Зубаревич, Четьре России, „Ведомости” 2011, 30 XII. 
wości społecznej, występując w Moskwie pod hasłem „Dość karmienia Kaukazu!”, nieoczekiwanie usłyszeli w odpowiedzi z rosyjskich regionów na Syberii - „Dość karmienia Moskwy!" [lecz nie: Dość karmienia Syberii, Dalekiego Wschodu, Uralu, Powotża, okolic podmoskiewskich (...) - jak stwierdza w swoim artykule Władimir Putin - W.A.] oraz propozycje ustanowienia Republiki Syberyjskiej w składzie Federacji Rosyjskiej oraz zaprzestania płacenia podatków (z wyjątkiem $5 \%$ przeznaczonych na utrzymanie armii) lub całkowitego oddzielenia się ${ }^{54}$.

W republikach narodowych groźba rozpadu kraju napawa coraz mniejszym lękiem. A wezwanie do ratowania się w pojedynkę brzmi coraz bardziej atrakcyjnie. Nie jest przypadkiem, że już dziś ponownie odbywają się w nich, na razie mało liczne, mitingi z żądaniami „Wolności!” i „Niepodległości!”, a także przeprowadzane są publiczne akcje prowokacyjne.

Niektórzy rosyjscy badacze konstatują: milczące i otwarte sprzyjanie [władz - W.A.] nacjonalizmowi coraz częściej wylewa się na ulice stolic Rosji, a te ekscesy z kolei wywotuja nieadekwatnie silna reakcje $w$ republikach narodowych [i nie tylko - W.A]. Prawdopodobnie wnajbliższej przysztości wielkoruski nacjonalizm, mający warunkowe poparcie systemu i bezwzględne zrozumienie u większości wyborców, mocno wstrzą́nie rosyjską scena polityczna ${ }^{55}$.

Jednocześnie eksperci zauważają nieadekwatność i nieskuteczność „reakcji” centrum na „wyzwania” z regionów: Metody kontroli [centrum nad regionami - W.A.], które są wykorzystywane w dzisiejszej Rosji, częściowo opierają się na modelu imperialnym $i$ dlatego sa drogie i nieoptacalne. Tylko okresowo w czasie wzrostu cen ropy naftowej można hojnie obdzielić agentów centrum w terenie. Przy zmniejszeniu się wptywów z eksportu i trwajacego spadku ekonomicznego mechanizmy imperialne okaża się nieakceptowalnie drogie, a tym samym niewydolne $e^{56}$.

Ponadto, dysponując tylko informacjami pochodzącymi od mianowanych gubernatorów, którzy są bardzo zmotywowani do upiększania sytuacji oraz - od nieefektywnego aparatu kontroli, centrum federalne jest zmuszone reagować na już nabrzmiałe i dające o sobie znać sytuacje nadzwyczajne, w rodzaju masowych protestów czy katastrof technologicznych, tracąc możliwość podjęcia działań prewencyjnych.

Niemniej, w opinii większości badaczy rosyjskich: dla federalizmu nie ma i nie może być alternatywy, jeśli Rosja chce zachować integralność terytorialna, nie popadajac przy tym $w$ autorytaryzm ${ }^{57}$. Jednak w warunkach rosyjskich alternatywą dla modelu imperialnego, zdaniem Iriny Busyginy i Michaiła Filippowa, nie jest klasyczny federalizm w stylu amerykańskim ani tym bardziej zwiąkowa wersja niemiecka czy austriacka, lecz asymetryczna federacja etniczna, w której znaczne dotacje dla mniej-

54 О. Алменова, Что для Москвы Кавказ, то для Сибири - Москва, „Власть. Аналитический еженедельник" 2011, nr 42 (946), s. 30.

55 А. Захаров, „Спящий институт”..., s. 122.

56 И. Бусыгина, М. Филиппов, Проблемь вынужденной федерализации, „Pro et Contra” 2009, nr 3-4 (46), s. 134.

57 Н. Н. Петров, Оптимизация политической системь, [w:] Повестка дня нового президентства, red. М. Аипман, Москва 2012, s. 30. 
szości (narodowych) sa nadal konieczne. Jednak w porównaniu z modelem imperialnym $w$ federacji etnicznej wspieranie integralności terytorialnej jest mimo wszystko znacznie tańsze dla większości. W federacji tego typu bezpośrednie kupowanie lojalności elit etnicznych cześsciowo zostaje zastapione przez redystrybucje praw i przywilejów $w^{58}$.

Zakłada to m.in. znaczącą zmianę podziału funkcji pomiędzy centrum federalnym i regionami na podstawie zasady subsydiarności, czyli delegowania funkcji od dotu ku górze i realizacji kazdej z nich na minimalnie wysokim poziomie, bliskim obywatelom jako źródtu wtadzy ${ }^{59}$.

Jednakże w związku z tym pojawiają się co najmniej dwa trudne pytania. Po pierwsze, kto może być podmiotem proponowanej redystrybucji kompetencji władzy w ramach obecnego systemu politycznego w Rosji? Po drugie, Busygina i Filippow sami podkreślają, że model federalizmu etnicznego jest o wiele bardziej złożony niż model imperialny, a jego realizacja wymaga kunsztu politycznego. Skąd jednak wezmą się odpowiedzialne i mądre elity oraz zarządzający zdolni do stworzenia „funkcjonującej federacji etnicznej"? Jak zauważył Andriej Zacharow, organiczne potaczenie wiernopoddańczej stużalczości w obecności zwierzchnictwa $z$ instynktami $i$ zwyczajami drobnego tyrana pod jego nieobecność zawsze byty jedna z najbardziej interesujacych cech rosyjskiego biurokraty ${ }^{60}$.

Jeśli w latach 90. wybrani w wyborach powszechnych prezydenci i elity republik w składzie Federacji Rosyjskiej zdołali „oswoić” i skanalizować agresywny etnonacjonalizm mniejszości, wykorzystać go jako walor w negocjacjach z federalnym centrum dotyczących specjalnego statusu i preferencji ekonomicznych, to dzisiaj, gdy nacjonalizm głęboko zakorzenił się w tkance systemów politycznych republik, okrzepł intelektualnie i organizacyjnie, mianowani przez centrum szefowie władzy wykonawczej wolący podporządkowywać się poleceniom przychodzącym z Kremla, niż działać zgodnie z interesami ludności regionów, najprawdopodobniej nie poradzą sobie z tym zadaniem. Przy czym przywrócenie zasady wybieralności szefów władzy wykonawczej niczego w zasadzie nie zmienia. Konsekwencją może być próba zakwestionowania integralności terytorialnej Rosji.

Tłumaczenie: Magdalena Romanowska

\section{BIBLIOGRAFIA}

Алменова О., Что для Москвы Кавказ, то для Сибири - Москва, „Власть. Аналитический еженедельник” 2011, nr 42 (946).

Афанасьев М. Н., Невььносимал слабость государства, Москва 2006.

58 И. Бусыгина, М. Филиппов, Проблемьь..., s. 134.

59 Н. Петров, Оптимизация политической системы..., s. 30.

60 А. Захаров, „Спящий институт”..., s. 110. 
Банс В., „Поздно сбросили” (Интервью Валерии Банс журналу „Эксперт”, nr 11 (505) от 20.03.2006), [w:] Русские чтения, шуd. 3, Москва 2006.

Бусыгина И., Фикиппов М., Проблемь вынужденной федерализации, „Pro et Contra” 2009, nr 3-4 (46).

Выступление президента РФ В. В. Путина на заседании Правительства РФ с участием глав региональньх администрачий, Москва, 13 IX 2004, [online] http://kremlin.ru/ text/appears/2004/09/76651.shtml.

Галмямов Р., Политические элитьь российских республик: особенности трансформачии в постсоветский период, [w:] Трансформачия российских региональньх элит в сравнительной перспективе, red. А. Мельвимь, Москва 1999.

Гельман В., Региональная власть в современной России: институть, режимь и практики, „ПОАИС” 1998, nr 1.

Горовиц А., Аемократия в разделенных обществах, nr spec. pisma „ГАобальные проблемы переходного периода" 1993, nr 6.

Грибанова Г. И., Сидоренко А. В., Федерализм и разрешение этнополитических конфликтов в современном обществе, „Политическая экспертиза: ПОАИТЭКС” 2007, Vol. 3, nr 3.

Аоктрина регионального развития Российской Федерации: Мини проект, red. С. С. Сулакшин i in., Москва 2009.

Аробижева $\Lambda$. М., Этничность в сочиально-политическом пространстве Российской Федерации, Москва 2013.

Захаров А., „Спящий институт”: Федерализм в современной России и в мире, Москва 2012.

Захаров А. А., Epluribus ипит. Очерки современного федерализма, Москва 2003.

Зубаревич Н., Сочиоэкономические различия между этническими регионами и политика перераспределения, [w:] Федерализм и этническое разнообразие в России. Сб. ст., red. И. Бусыгина, А. Хайнеманн-Грюдер, Москва 2010.

Зубаревич Н., Четьце России, „Ведомости” 2011, 30 XII.

Иванченко А. А., Организачионно-правовое обеспечение приоритетов регионального развития, [w:] Конституционно-правовьь проблемьь развития российского федерализма, Москва 2000.

Каган В. Е., Ното Xепophobicus: nсихология „своего и чужого”, „Национальный психологический журнал" 2011, nr 2 (6).

Казула Ф., Разделенное государство: федерализм как агонизм начий?, [w:] Кновоймодели российского федерализма, red. А. Захароа, О. ЗАравомысловой, А. Рябов, Москва 2013.

Карапетян А. М., Федерализм и права народов: Курс лекиий, Москва 1999.

Кимлика У., Современная политическая философия: введение, Москва 2010.

Магомедов А. К., Российский правящий класс и „исламскал альтернатива”: к новому осмьслению политического, [w:] Власть и элитьь в российской трансформачии, red. А. Аука, Санкт-Петербург 2005.

Мамашенко А., Новъцй президент и „старый” Северный Кавказ, [w:] Повестка дня нового президентства, red. М. Аипман, Москва 2012.

Миронюк М. Г., Современный федерализм: Сравнительный анализ, Москва 2008. 
Морено А., Многообразие и единство в федеративньц государствах мира, „Политическая наука", 2011, nr 1: Этничность и политика, red. nr О. Ю. Малинова.

Народовластие в России - очерк истории и современного состояния, red. Ю. А.Амитриев, Москва 1997.

Осипов А., Эссенщиалистские представления об этничности в системах преподавания правовых специальностей, [w:] Расизм в языке образования, red. В. Воронков, О. Карпенко, А. Осипов, Санкт-Петербург 2008.

Панкевич Н. В., Модели федеративного устройства: закономерности политической трансформации, Екатеринбург 2008.

Петров Н., Оптимизация политической системь, [w:] Повестка дня нового президентства, red. М. Аипман, Москва 2012.

Путин В. В., Россия: Национальньй вопрос, „Независимая газета” 2012, 23 I.

Розов Н. С., Теории исторической динамики Рэндалла Коллинза и контексте российской помитики, „Полис” 2012, nr 6.

Сагитова $\Lambda .$, Региональная идентичность: сочиальнье детерминанты и конструктивистская деятельность СМИ (на примере Республики Татарстан), [w:] Центр и региональньце идентичности в России, red. В. Гельман, Т. Хопф, Санкт-Петербург 2003.

Соколовский С. В., Перспективы развития концепции этнонациональной политики в Российской Федерачии, Москва 2004.

Стародубцев А., Бесполезное достижение? Губернаторские выборы в контексте проблем регионального развития, „Неприкосновенный запас” 2012, nr 4.

Степанов В., Рейтинг конфликтности государств и регионов по данным Сети этнологического мониторинга за 2010 год, [w:] Этнополитическая ситуачия в России и сопредельньцх государствах: Ежегодньий доклад, red. В. Тишков, В. Степанов, Москва 2011.

Червонная С.М., Абхазия-1992: посткоммунистическая Вандея, Москва 1993.

Шевцова $\Lambda .$, Россия - год 2006: логика политического страха, cz. 2, „Независимая газета” 2005, 16 XII.

Шнирельман В., „Патриотическое воспитание”: этнические конфликты и икольнысе учебники истории, [w:] Расизм в язьке образования, red. В. Воронков, О. Карпенко, А. Осипов, Санкт-Петербург 2008.

Фикиппов В. Р., Кризис этнического федерализма в России, [w:] Регионьь и регионализм в странах Запада и России, Москва 2001.

Холодковский К. Г., Самоопределение России, Москва 2013.

Federalism: the Multiethnic Challenge, red. G. Smith, London-New York 1995.

Filippov V., Ordeshook P., Shvetsova O., Designing Federalism: A Theory of Self-Sustainable Federal Institutions, Cambridge 2004.

Jeffery Ch., The Non-Reform of the German Federal System after Unification, „West European Politics" 1995, Vol. 18.

Kymlicka W., Multicultural Citizenship: A Liberal Theory of Minority Rights, Oxford 1995.

Malloy T. H., National Minority Rights in Europe, Oxford 2005.

McGarry J., O’Leary B., Explaining Northern Ireland: Broken Images, Oxford-Cambridge 1995.

McCarry J., O'Leary B., Introduction: The Macro-Political Regulation of Ethnic Conflict. The Po- 
litics of Ethnic Conflict Regulation: Case Studies of Protracted Ethnic Conflict, London-New York 1993.

McGarry J., O'Leary B., The Politics of Ethnic Conflict Regulation: Case Studies of Protracted Ethnic Conflicts, London 1993.

Treisman D., After the Deluge. Regional Crises and Political Consolidation in Russia, Ann Arbor 1999.

Walerij Aleksiejewicz ACZKASOW - doktor habilitowany nauk politycznych, profesor, kierownik Katedry Międzynarodowych Procesów Politycznych na Wydziale Politologii Petersburskiego Uniwersytetu Państwowego. 